\title{
Nanoparticle-Based Antimicrobials: Surface Functionality is
}

\section{Critical [version 1; peer review: 2 approved]}

\author{
Akash Gupta, Ryan F. Landis, Vincent M. Rotello
}

Department of Chemistry, University of Massachusetts Amherst, 710 North Pleasant Street, Amherst, Massachusetts, 01003, USA

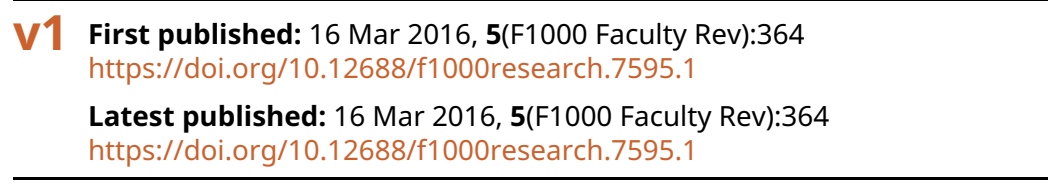

\section{Abstract}

Bacterial infections cause 300 million cases of severe illness each year worldwide. Rapidly accelerating drug resistance further exacerbates this threat to human health. While dispersed (planktonic) bacteria represent a therapeutic challenge, bacterial biofilms present major hurdles for both diagnosis and treatment. Nanoparticles have emerged recently as tools for fighting drug-resistant planktonic bacteria and biofilms. In this review, we present the use of nanoparticles as active antimicrobial agents and drug delivery vehicles for antibacterial therapeutics. We further focus on how surface functionality of nanomaterials can be used to target both planktonic bacteria and biofilms.

\section{Keywords}

Antimicrobials, nanoparticles, bacteria, biofilms, antibacterial

\section{Open Peer Review}

Approval Status

1

2

version 1

16 Mar 2016

Faculty Reviews are review articles written by the prestigious Members of Faculty Opinions. The articles are commissioned and peer reviewed before publication to ensure that the final, published version is comprehensive and accessible. The reviewers who approved the final version are listed with their names and affiliations.

\section{Marco Siccardi, University of Liverpool,}

Liverpool, UK

2. Charles Flexner, Johns Hopkins University,

Baltimore, USA

Any comments on the article can be found at the end of the article. 
Corresponding author: Vincent M. Rotello (rotello@chem.umass.edu)

Competing interests: The authors declare that they have no competing interests.

Grant information: This research was funded by the National Institutes of Health (GM077173) and the National Science Foundation (CHE- 1307021).

The funders had no role in study design, data collection and analysis, decision to publish, or preparation of the manuscript.

Copyright: @ 2016 Gupta A et al. This is an open access article distributed under the terms of the Creative Commons Attribution License, which permits unrestricted use, distribution, and reproduction in any medium, provided the original work is properly cited.

How to cite this article: Gupta A, Landis RF and Rotello VM. Nanoparticle-Based Antimicrobials: Surface Functionality is Critical [version 1; peer review: 2 approved] F1000Research 2016, 5(F1000 Faculty Rev):364 https://doi.org/10.12688/f1000research.7595.1

First published: 16 Mar 2016, 5(F1000 Faculty Rev):364 https://doi.org/10.12688/f1000research.7595.1 


\section{Introduction}

Bacterial infections cause 300 million cases of severe illness every year with 16 million, including 2 million children, killed ${ }^{1}$. Infections caused by multi-drug-resistant (MDR) bacteria greatly increase the threat generated by bacterial infections. In addition to acute illness, bacterial infections can result in chronic disease states, where bacterial colonization develops into a biofilm, a complex three-dimensional bacterial community ${ }^{2}$. The complexity of the biofilm matrix makes biofilm-associated diseases more clinically challenging than planktonic bacteria in both diagnosis and treatment ${ }^{3}$. Finally, there has been a significant decrease in the number of approved antibiotics recently, contributing to the urgency of developing alternative antimicrobial agents ${ }^{4}$.

Nanoparticles (NPs) are emerging as weapons in our antimicrobial arsenal owing to their unique nanoscale physical and chemical properties $^{5,6}$. For example, NP size is commensurate with biomolecular and bacterial cellular systems, providing a platform where nanomaterial-bacteria interactions can be fine-tuned through appropriate surface functionalization ${ }^{7,8}$. Moreover, the high surface area to volume ratio of nanomaterials enables high loading of therapeutics, with promising synergy arising from multivalent interactions. NPs provide a way to address the common mechanisms of antibiotic resistance, such as permeability regulation ${ }^{9,10}$, multi-drug efflux pumps $^{11}$, antibiotic degradation ${ }^{12,13}$, and target site binding affinity mutations ${ }^{14}$. NPs also provide alternative pathways to combat biofilm/MDR infections and significantly lower bacteria resistance over time ${ }^{15-17}$. NPs utilize multiple mechanisms to kill bacteria, making it difficult for them to adapt existing strategies for developing resistance $^{18}$. Following this strategy, several NP-based systems have been developed to improve antimicrobial efficacy (Figure 1) (19-21. $^{19}$. In this review, we will focus on recent studies that use engineered NPs as active therapeutic agents or as delivery vehicles to transport drugs to the site of infection.

\section{Nanoparticle interactions with bacteria and biofilms}

Engineering the interactions of nanomaterials with bacteria/biofilm matrices plays a crucial role in designing NP-based antimicrobial systems. The surface properties of NPs are highly versatile and can be easily modulated through ligand engineering to generate particles with new and emergent properties ${ }^{22-24}$. These NPs can be utilized for not only therapeutic applications but also fundamental studies on bacterial behavior. In early studies of NP-microbe interactions, Rotello and co-workers showed that cationic gold NPs (AuNPs) possessed toxicity against bacteria ${ }^{25}$. Subsequently, they demonstrated that hydrophobic, cationic AuNPs developed spatiotemporal aggregate patterns on the bacterial surface. The aggregate patterns depended upon the nature of the bacteria as well as the size of the NPs. In this work, $6 \mathrm{~nm}$ AuNPs were found to have low toxicity, whereas $2 \mathrm{~nm}$ AuNPs rapidly lysed Bacillus subtilis but not Escherichia coli ${ }^{26}$. In a similar study, Feng and co-workers further corroborated the fact that NP and bacterial surface chemistry impact NP-bacteria interactions and toxicity. They reported that the NPs with maximal cationic charge associated most significantly with the bacterial surfaces, inducing the greatest membrane damage and toxicity ${ }^{27}$. These studies provide valuable insight into designing therapeutic constructs for planktonic bacteria treatment.

Bacteria can self-colonize to form biofilms. Biofilm infections are difficult to treat because the extracellular matrix produced by bacteria creates a microenvironment within the host. This allows bacteria to evade immune responses and dramatically increase resistance to traditional antibiotic treatments ${ }^{28,29}$. The complex architecture, dynamics, and composition of extracellular polymeric substances (EPS) in the matrix are profoundly responsible for the low penetration of therapeutic agents ${ }^{30}$. Diffusion of therapeutics inside the biofilm can be affected by several genetic and physiological heterogeneities such as the hydrophobicity of bacterial cell walls ${ }^{31}$.

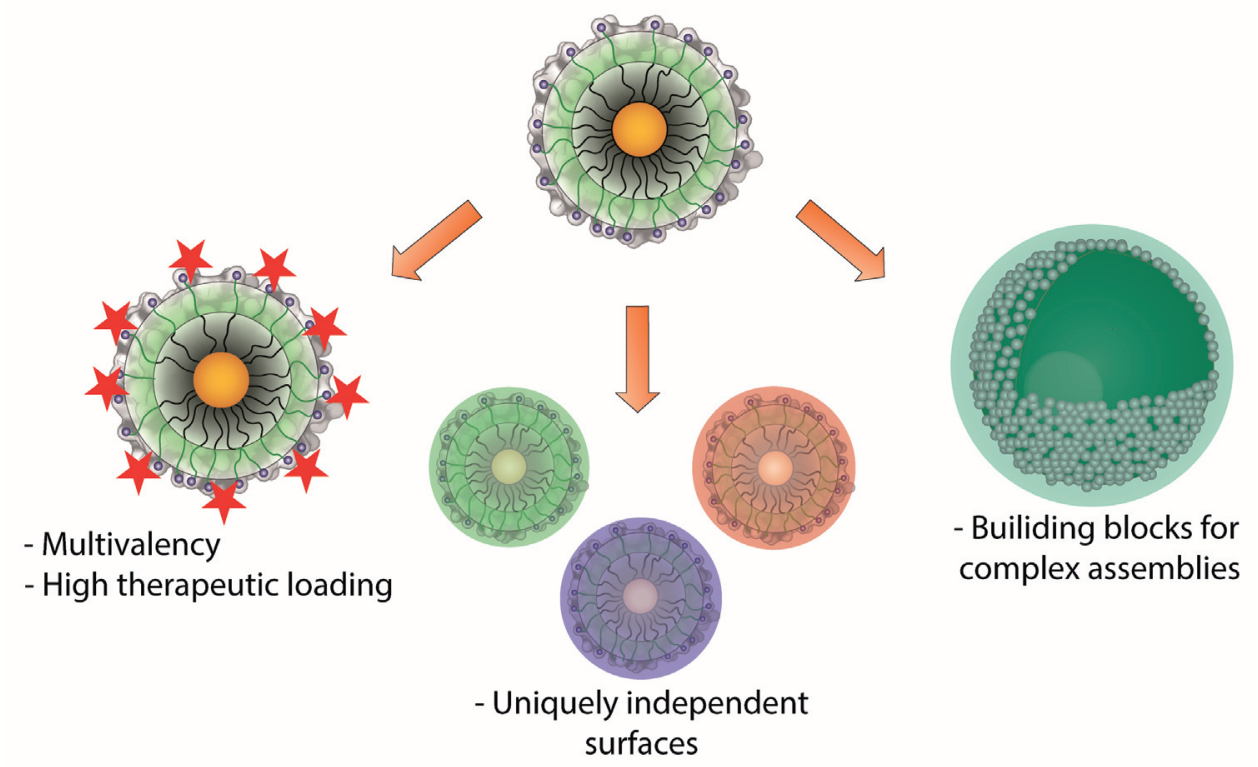

Figure 1. Nanoparticles as scaffolds and building blocks for antimicrobial agents. 
Hence, fundamentally understanding the interactions between NPs and complex biofilm matrices is crucial in designing materials for biofilm treatment.

The penetration and deposition of NPs within the biofilms are key components for the design of biofilm therapeutics. Peulen and Wilkinson reported that the penetration ability of NPs decreased inversely to their size due to small pore sizes within biofilms ${ }^{32}$. Furthermore, NP deposition inside the biofilms is largely dependent upon the electrostatic interaction as well as the homogeneity of the charges across the biofilm surface. In a related study, Rotello and co-workers provided further insight on the penetration ability of the NPs inside the biofilms. They demonstrated that the neutral and anionic quantum dots (QDs) did not show any penetration inside the biofilms, while cationic QDs were widely distributed throughout the biofilm. Furthermore, cationic QDs with hydrophobic terminal groups were found inside the bacterial cells, whereas their hydrophilic counterparts remained in the EPS matrix of the biofilm (Figure 2) $)^{33}$.

\section{Nanoparticles as active antimicrobial agents}

NPs provide multiple attributes that facilitate the development of unique antimicrobial strategies ${ }^{34,35}$. NPs can interact with and penetrate bacterial cells with unique bacteriostatic and bactericidal mechanisms ${ }^{36}$. For example, possessing slightly larger diameters than drug efflux pumps, NPs can potentially reduce efflux-mediated extrusion $^{37,38}$. Exploiting these characteristic properties, several NP-based systems have been employed for antimicrobial applications. $\mathrm{Xu}$ and co-workers demonstrated enhanced in vitro antibacterial activities of vancomycin-capped AuNPs (Au-Van) against vancomycin-resistant enterococci and E. coli strains ${ }^{39}$. Similarly, Feldheim and co-workers demonstrated that antimicrobial activity of NPs functionalized with non-antibiotic molecules depended upon their composition on the surface ${ }^{40}$. These studies indicate that modulating NP surfaces exhibits great potential for antimicrobial therapy. However, further studies on how NP surface functionality modulates antimicrobial activity can provide valuable information for future NP-based antimicrobial agents.

In a recent study, the Rotello group reported a strategy to combat MDR bacteria by engineering the ligands on NP surfaces. Cationic and hydrophobic functionalized AuNPs effectively suppressed the growth of 11 clinical MDR isolates at low concentrations (Figure 3). The minimum inhibitory concentrations (MICs) observed for these systems with most bacteria strains was $16 \mathrm{nM}$. Moreover, bacteria strains did not develop resistance against NPs, even after 20 passages

a)
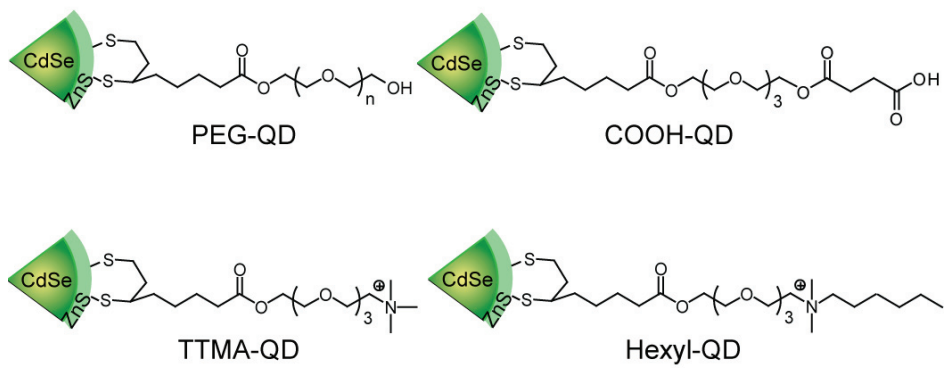

b)

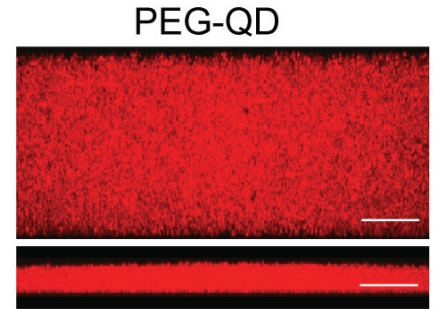

TTMA-QD

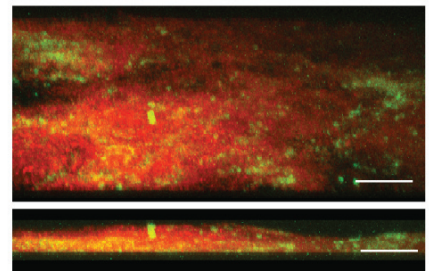

$\mathrm{COOH}-\mathrm{QD}$

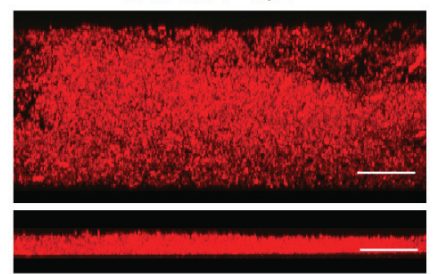

Hexyl-QD

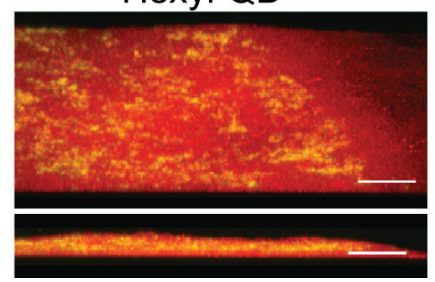

Figure 2. Surface design controls penetration ability of nanoparticles. a) Quantum dots used in study. b) Micrographs of microtomed slices of the biofilm showing no penetration by anionic and neutral particles and efficient infiltration by cationic quantum dots ${ }^{33}$. 
a)
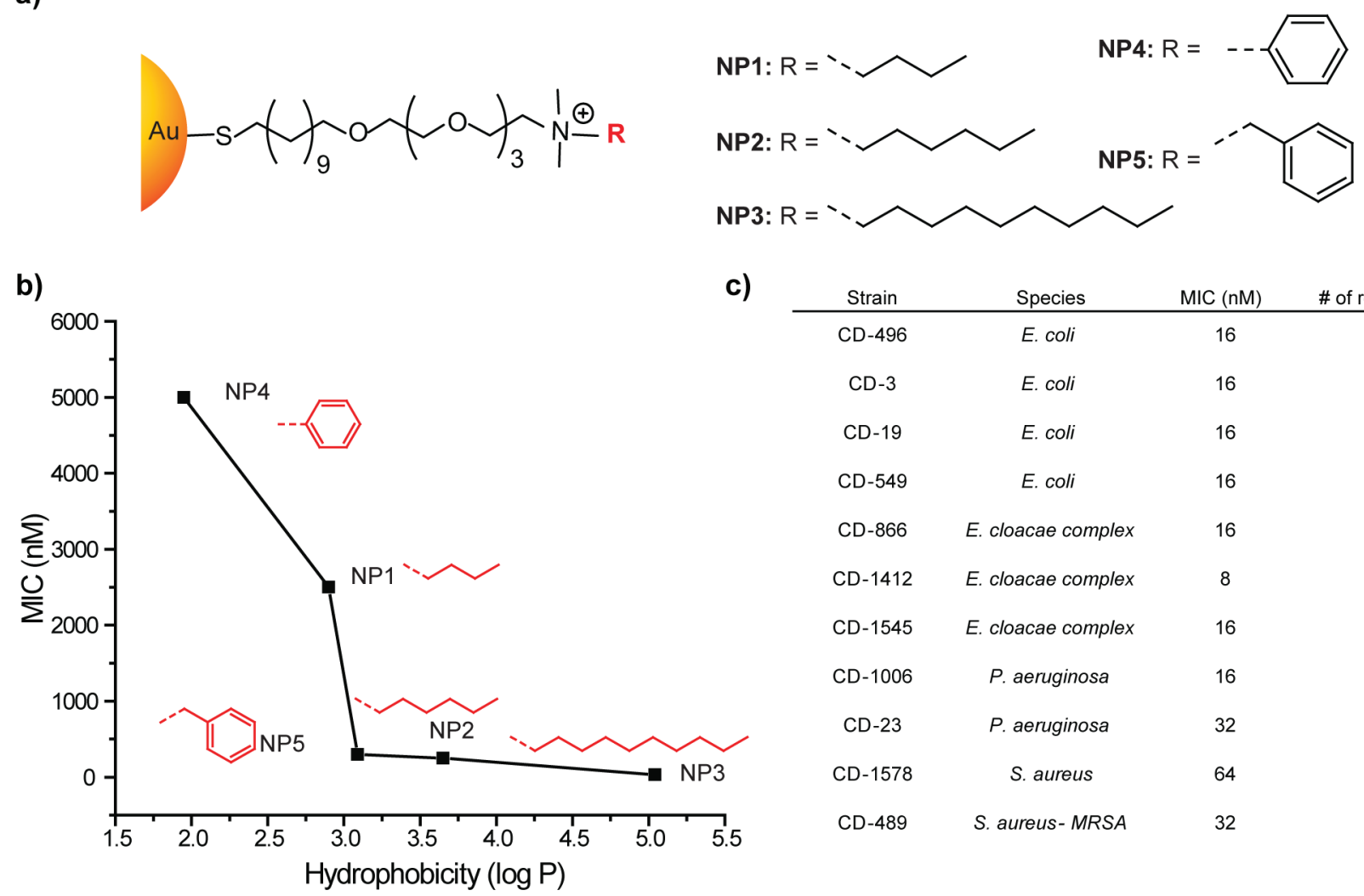

c)

\begin{tabular}{cccc} 
Strain & Species & MIC $(\mathrm{nM})$ & \# of resistant drugs \\
\hline CD-496 & E. coli & 16 & 2 \\
CD-3 & E. coli & 16 & 3 \\
CD-19 & E. coli & 16 & 4 \\
CD-549 & E. coli & 16 & 17 \\
CD-866 & E. cloacae complex & 16 & 2 \\
CD-1412 & E. cloacae complex & 8 & 4 \\
CD-1545 & E. cloacae complex & 16 & 7 \\
CD-1006 & P. aeruginosa & 16 & 1 \\
CD-23 & P. aeruginosa & 32 & 13 \\
CD-1578 & S. aureus & 64 & 4 \\
CD-489 & S. aureus- MRSA & 32 & 10 \\
& & &
\end{tabular}

Figure 3. Functionalized gold nanoparticles as antimicrobial agents. a) Nanoparticles studied, featuring $2 \mathrm{~nm}$ gold cores. b) Toxicity of nanoparticles to a laboratory Escherichia coli strain. c) Minimum inhibitory concentrations of nanoparticle 3 against multi-drug-resistant bacteria ${ }^{41}$.

at sub-MIC concentrations, which is far beyond that of traditional antibiotics ${ }^{41}$. Overall, this study provides an excellent starting platform to design antibacterial therapeutics in future studies.

The antibacterial activity of silver has been well established. High surface area and concomitant increase in dissolution rate are key to its use in silver-based antimicrobials, where free $\mathrm{Ag}^{+}$ions are the active agents ${ }^{42}$. However, they face certain shortcomings, such as high toxicity to mammalian cells and limited penetration in biofilm matrices ${ }^{43,44}$. Recent studies have focused on countering these issues by using inherent NP properties and surface functionalization as their toolkit. For example, Mahmoudi and co-workers developed silver ring-coated superparamagnetic iron oxide NPs (SPIONS) with ligand gaps that demonstrated high antimicrobial activity and remarkable compatibility with healthy cells. Additionally, these NPs exhibited enhanced activity against biofilm infections due to deeper penetration under an external magnetic field ${ }^{45}$.

Graphene $\mathrm{NPs}^{46}$, AuNPs ${ }^{47}$, and carbon nanotubes ${ }^{48}$ possess photothermal properties that can be utilized to design therapeutic agents. These nanomaterials absorb light (700-1100 nm) and release heat. Ling and co-workers designed graphene-based photothermal NPs that captured and killed Staphylococcus aureus and E. coli bacteria upon near-infrared (NIR) laser irradiation. In this approach, graphene oxide was reduced and functionalized with magnetic NPs (MRGO). These NPs were functionalized with glutaraldehyde (GA) to induce excellent crosslinking properties with Gram-positive and Gram-negative bacteria (Figure 4). Rapid and effective killing of $99 \%$ of both bacterial species was achieved upon NIR irradiation ${ }^{49}$.

\section{Nanoparticles as drug delivery vehicles for antibacterial therapy}

Bacterial infections are able to evade antibiotic treatment through reduced bactericidal concentration or reduced antimicrobial activity of therapeutic agents at the site of infection ${ }^{50,51}$. Localized delivery of the drugs/antimicrobials can increase their therapeutic efficacy. Therefore, NPs can serve as promising drug delivery vehicles owing to their tunable surface functionality, biocompatibility, and high drug loading capacity ${ }^{17}$.

NPs such as mesoporous silica possess a uniquely large surface area and tunable pore size that make them promising candidates for designing drug delivery vehicles ${ }^{52}$. For example, Schoenfisch and co-workers designed amine-functionalized silica NPs that were able to readily penetrate and eradicate pathogenic biofilms through rapid 


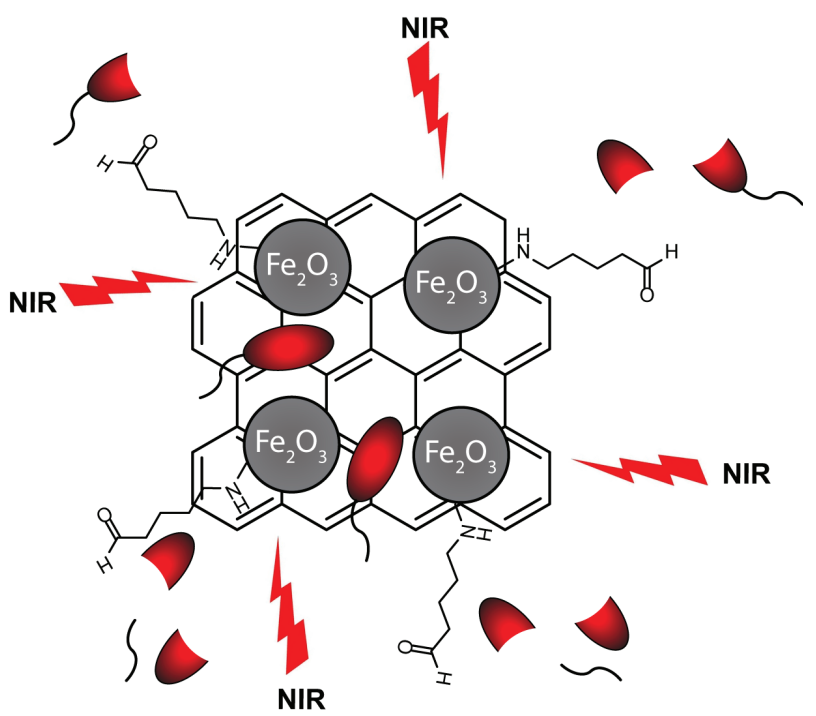

Figure 4. Schematic representation of antibacterial photothermal treatment by mildly reduced graphene oxide functionalized with glutaraldehyde.

nitric oxide release ${ }^{53}$. Similarly, silica NPs have been fabricated as scaffolds for silver NP (AgNP) release ${ }^{54}$. Using NPs for controlled antimicrobial release can markedly improve their biocompatibility with mammalian cells and mitigate their hazardous environmental impact ${ }^{55-57}$. In one such study, biodegradable lignin-core NPs (EbNPs) infused with silver ions were proposed as greener alternatives to AgNPs. EbNPs were coated with cationic polyelectrolytes and loaded with $\mathrm{Ag}^{+}$ions. These NPs exhibited broad-spectrum biocidal action against Gram-positive and Gram-negative bacteria at lower $\mathrm{Ag}^{+}$ion concentrations than conventional $\mathrm{AgNPs}^{58}$.

Therapeutic selectivity is critical when designing effective drug delivery vehicles. Triggered release of antimicrobials from these nanocarriers can be an alternative strategy to diminish their undesirable side effects ${ }^{59,60}$. In one particular study, Langer and co-workers designed PLGA-PLH-PEG NPs as a carrier to deliver vancomycin to bacterial cells, exploiting their localized acidity. PLGA-PLH-PEG NPs demonstrated high binding affinity to bacterial cells at $\mathrm{pH} 6.0$ as compared to 7.4. Vancomycin-encapsulated NPs exhibited a 1.3-fold increase in the MIC against $S$. aureus as compared to 2.0-fold and 2.3-fold for free and PLGA-PEGencapsulated vancomycin, respectively ${ }^{61}$. In a similar study, pH-responsive NPs were used to deliver hydrophobic drugs to biofilm moieties. Polymeric NPs used in this study consisted of a cationic outer shell to bind with the EPS matrix and a $\mathrm{pH}$-responsive hydrophobic inner shell to release encapsulated farnesol molecules on demand. These scaffolds resulted in a 2-fold increase in efficacy in the treatment of biofilms as compared to the drug alone ${ }^{62}$.

Apart from acidic microenvironments, NPs can be designed to trigger antibiotic release upon exposure to bacterial toxins. For example, Zhang and co-workers designed AuNP-stabilized phospholipid liposomes (AuChi-liposomes) that respond to bacterial toxins. Chitosan-functionalized AuNPs were adsorbed on the liposomal surfaces to provide stability and prevent undesirable antibiotic leakage. In the presence of $\alpha$-toxin-secreting $S$. aureus bacteria, AuChi-liposomes released vancomycin that effectively inhibited their growth ${ }^{63}$.

Cationic NPs exhibit excellent penetration ability in biofilms ${ }^{64}$. Moreover, they can self-assemble at the oil-water interfaces to generate nanocapsules ${ }^{65}$. Combining these two characteristic features, Rotello and co-workers generated a highly effective therapeutic system for the treatment of bacterial biofilm infections. Peppermint oil and cinnamaldehyde were chosen as the therapeutic oil template, owing to their inherent antimicrobial nature, in combination with amine-functionalized cationic silica NPs that stabilized the oil-water interface to generate nanocapsules (CP-caps) (Figure 5). These capsules were further stabilized by the formation of hydrophobic Schiff bases upon reacting with cinnamaldehyde. The cationic NPs enabled the capsules to readily penetrate the biofilms and release the antimicrobial oils to eradicate the biofilm infections. Moreover, the therapeutic selectivity of CP-caps was a)

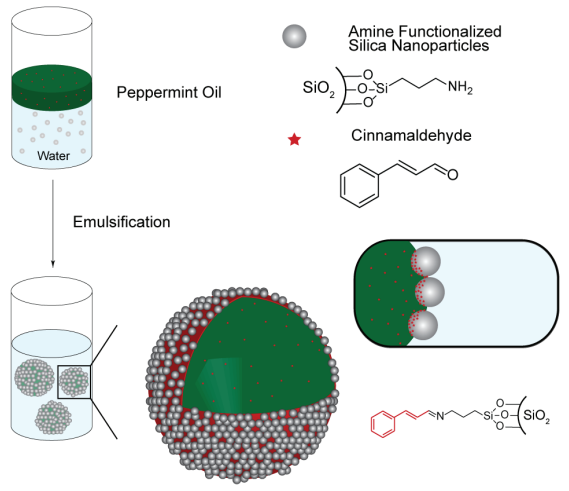

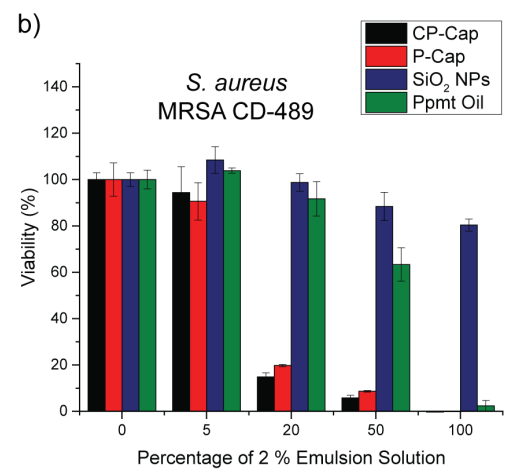

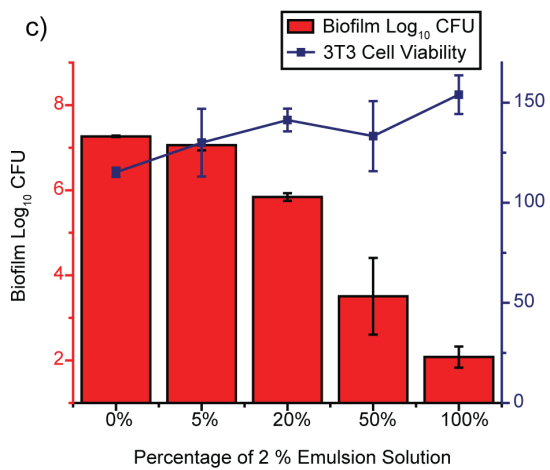

Figure 5. Nanoparticle-stabilized capsules for treatment of biofilm infections. a) Fabrication of capsules. b) Efficacy of cinnamaldehyde dissolved in peppermint oil capsule (CP-Cap) and controls against a clinical isolate of methicillin-resistant Staphylococcus aureus. c) Toxicity of CP-Cap against Escherichia coli cells while enhancing fibroblast viability ${ }^{66}$. 
tested on a biofilm-fibroblast cell co-culture model. These studies showed effective biofilm infection eradication with simultaneous growth enhancement of fibroblast cells ${ }^{66}$.

High therapeutic selectivity makes these capsules useful antimicrobial agents for topical administration. Use of these nanomaterials systemically, however, requires an understanding of NP pharmacokinetics (PK) and biodistribution (BD). The PK and BD properties of NPs depend on several factors such as their size, shape, and surface functionalization ${ }^{67,68}$. Apart from their physiochemical characteristics, the administration route of NPs likewise determines their systemic or local effect. For example, intravenous injection is used for targeting the liver and spleen, whereas mucoadhesive NPs are used for oral and nasal drug delivery ${ }^{69}$. Similarly, uptake and elimination of NPs in cells/tissues are dependent upon their physiochemical properties ${ }^{70}$. For example, cationic NPs have higher uptake and slower rate of exocytosis in cells as compared to their anionic counterparts ${ }^{25,71}$. Hence, evaluating the PK behavior of the current antimicrobial systems is important for their translation into the clinic.

\section{Conclusion}

NPs provide a versatile platform in designing materials for antimicrobial therapy. Tunable surface functionality and multivalency makes them promising candidates to target planktonic bacteria. Moreover, excellent biofilm penetration enhances their activity towards a range of biofilm-based infections. NP-based antimicrobial agents can be readily used for ex vivo applications such as sterilizers for surfaces and devices. The most accessible target in the near future includes the topical applications of NP-based systems for wound healing. However, further studies at the fundamental, biological, and pharmacological level are required to enable systemic administration of these antimicrobials. In conclusion, NPs have offered promising avenues to design effective next-generation therapeutics against bacterial threats.

\section{Abbreviations}

AgNP, silver nanoparticle; AuChi-liposomes, AuNP stabilized phospholipid liposomes; AuNPs, gold nanoparticles; Au-Van, vancomycin-capped AuNPs; CP-caps, cinnamaldehyde dissolved in peppermint oil capsules; EbNPs, lignin-core nanoparticles; EPS, extracellular polymeric substances; GA, glutaraldehyde; MDR, multi-drug resistance; MIC, minimum inhibitory concentration; MRGO, mildly reduced graphene oxide functionalized with magnetic nanoparticles; NIR, near-infrared; NPs, nanoparticles; PK, pharmacokinetics; PLGA-PLH-PEG, poly(D,L-lactic-co-glycolic acid)-b-poly(L-histidine)-b-poly-(ethylene glycol); QDs, quantum dots; SPIONS, superparamagnetic iron oxide nanoparticles.

\section{Competing interests}

The authors declare that they have no competing interests.

\section{Grant information}

This research was funded by the National Institutes of Health (GM077173) and the National Science Foundation (CHE- 1307021).

The funders had no role in study design, data collection and analysis, decision to publish, or preparation of the manuscript.
1. Prüss A, Kay D, Fewtrell L, et al.: Estimating the burden of disease from water, sanitation, and hygiene at a global level. Environ Health Perspect. 2002; 110(5): 537-42.

PubMed Abstract | Free Full Text

2. Costerton JW, Cheng KJ, Geesey GG, et al:: Bacterial biofilms in nature and disease. Annu Rev Microbiol. 1987; 41: 435-64. PubMed Abstract | Publisher Full Text

3. Costerton JW Stewart PS, Greenberg EP: Bacterial biofilms: a common cause of persistent infections. Science. 1999; 284(5418): 1318-22. PubMed Abstract | Publisher Full Text

4. Spellberg B, Powers JH, Brass EP, et al:: Trends in antimicrobial drug development: implications for the future. Clin Infect Dis. 2004; 38(9): 1279-86. PubMed Abstract | Publisher Full Text

5. De M, Ghosh PS, Rotello VM: Applications of Nanoparticles in Biology. Adv Mater. 2008; 20(22): 4225-41. Publisher Full Text

6. Davis ME, Chen ZG, Shin DM: Nanoparticle therapeutics: an emerging treatment modality for cancer. Nat Rev Drug Discov. 2008; 7(9): 771-82. PubMed Abstract | Publisher Full Text

7. Jiang Z, Le ND, Gupta A, et al.: Cell surface-based sensing with metallic nanoparticles. Chem Soc Rev. 2015; 44(13): 4264-74. PubMed Abstract | Publisher Full Text | Free Full Text

8. Daniel MC, Astruc D: Gold nanoparticles: assembly, supramolecular chemistry, quantum-size-related properties, and applications toward biology, catalysis, and nanotechnology. Chem Rev. 2004; 104(1): 293-346. PubMed Abstract | Publisher Full Text

9. Falagas ME, Kasiakou SK: Colistin: the revival of polymyxins for the management of multidrug-resistant gram-negative bacterial infections. Clin Infect Dis. 2005 40(9): 1333-41.

PubMed Abstract | Publisher Full Text

10. Cui L, Iwamoto A, Lian JQ, et al:: Novel mechanism of antibiotic resistance originating in vancomycin-intermediate Staphylococcus aureus. Antimicrob
Agents Chemother. 2006; 50(2): 428-38.

PubMed Abstract | Publisher Full Text | Free Full Text

11. Li XZ, Nikaido H: Efflux-mediated drug resistance in bacteria. Drugs. 2004; 64(2): 159-204.

PubMed Abstract | Publisher Full Text

12. Livermore DM: beta-Lactamases in laboratory and clinical resistance. Clin Microbiol Rev. 1995; 8(4): 557-84.

PubMed Abstract | Free Full Text

13. Davies J, Wright GD: Bacterial resistance to aminoglycoside antibiotics. Trends Microbiol. 1997; 5(6): 234-40.

PubMed Abstract | Publisher Full Text

14. Courvalin P: Vancomycin resistance in gram-positive cocci. Clin Infect Dis. 2006; 42(Suppl 1): S25-34.

PubMed Abstract | Publisher Full Text

15. Hajipour MJ, Fromm KM, Ashkarran AA, et al.: Antibacterial properties of nanoparticles. Trends Biotechnol. 2012; 30(10): 499-511. PubMed Abstract | Publisher Full Text

16. Miller $\mathrm{KP}$, Wang L, Benicewicz BC, et al:: Inorganic nanoparticles engineered to attack bacteria. Chem Soc Rev. 2015; 44(21): 7787-807. PubMed Abstract | Publisher Full Text

17. Huh AJ, Kwon YJ: "Nanoantibiotics": a new paradigm for treating infectious diseases using nanomaterials in the antibiotics resistant era. $J$ Control Release. 2011; 156(2): 128-45. PubMed Abstract | Publisher Full Text

18. Chopra I: The increasing use of silver-based products as antimicrobial agents: a useful development or a cause for concern? J Antimicrob Chemother. 2007; 59(4): 587-90. PubMed Abstract | Publisher Full Text

19. Jones N, Ray B, Ranjit KT, et al.: Antibacterial activity of ZnO nanoparticle suspensions on a broad spectrum of microorganisms. FEMS Microbiol Lett. 2008; 279(1): 71-6.

PubMed Abstract | Publisher Full Text 
20. Sondi I, Salopek-Sondi B: Silver nanoparticles as antimicrobial agent: a case study on E. coli as a model for Gram-negative bacteria. J Colloid Interface Sci. 2004; 275(1): 177-82.

PubMed Abstract | Publisher Full Text

21. Simon-Deckers A, Loo S, Mayne-L'hermite M, et al.: Size-, composition- and shape-dependent toxicological impact of metal oxide nanoparticles and carbon nanotubes toward bacteria. Environ Sci Technol. 2009; 43(21): 8423-9. PubMed Abstract | Publisher Full Text

22. Wang L, Gupta A, Rotello VM: Nanomaterials for the Treatment of Bacterial Biofilms. ACS Infect Dis. 2016; 2(1): 3-4.

Publisher Full Text

23. Moyano DF, Rotello VM: Nano meets biology: structure and function at the nanoparticle interface. Langmuir. 2011; 27(17): 10376-85. PubMed Abstract | Publisher Full Text | Free Full Text

24. Zhao $\mathrm{Y}$, Tian $\mathrm{Y}, \mathrm{Cui} \mathrm{Y}$, et al:: Small molecule-capped gold nanoparticles as potent antibacterial agents that target Gram-negative bacteria. J Am Chem Soc. 2010; 132(35): 12349-56.

PubMed Abstract | Publisher Full Text

25. Goodman CM, McCusker CD, Yilmaz T, et al:: Toxicity of gold nanoparticles functionalized with cationic and anionic side chains. Bioconjug Chem. 2004; 15(4): 897-900.

PubMed Abstract | Publisher Full Text

26. Hayden SC, Zhao G, Saha K, et al:: Aggregation and interaction of cationic nanoparticles on bacterial surfaces. J Am Chem Soc. 2012; 134(16): 6920-3. PubMed Abstract | Publisher Full Text

27. F Feng ZV, Gunsolus IL, Quu TA, et al.: Impacts of gold nanoparticle charge and ligand type on surface binding and toxicity to Gram-negative and Grampositive bacteria. Chem Sci. 2015: 6(9): 5186-96.

Publisher Full Text | F1000 Recommendation

28. Römling U, Balsalobre C: Biofilm infections, their resilience to therapy and innovative treatment strategies. J Intern Med. 2012; 272(6): 541-61.

PubMed Abstract | Publisher Full Text

29. Stewart PS, Costerton JW: Antibiotic resistance of bacteria in biofilms. Lancet. 2001; 358(9276): 135-8.

PubMed Abstract | Publisher Full Tex

30. Daddi Oubekka S, Briandet R, Fontaine-Aupart MP, et al:: Correlative time-resolved fluorescence microscopy to assess antibiotic diffusion-reaction in biofilms. Antimicrob Agents Chemother. 2012; 56(6): 3349-58.

PubMed Abstract | Publisher Full Text | Free Full Text

31. F Habimana O, Steenkeste K, Fontaine-Aupart MP, et al:: Diffusion of nanoparticles in biofilms is altered by bacterial cell wall hydrophobicity. Appl Environ Microbiol. 2011; 77(1): 367-8.

PubMed Abstract | Publisher Full Text | Free Full Text | F1000 Recommendation

32. F Peulen TO, Wilkinson KJ: Diffusion of nanoparticles in a biofilm. Environ Sci Technol. 2011; 45(8): 3367-73.

PubMed Abstract | Publisher Full Text | F1000 Recommendation

33. Li X, Yeh YC, Giri K, et al:: Control of nanoparticle penetration into biofilms through surface design. Chem Commun (Camb). 2015; 51(2): 282-5. PubMed Abstract | Publisher Full Text | Free Full Text

34. Peer D, Karp JM, Hong S, et al:: Nanocarriers as an emerging platform for cancer therapy. Nat Nanotechnol. 2007; 2(12): 751-60. PubMed Abstract | Publisher Full Text

35. Mout R, Moyano DF, Rana S, et al: Surface functionalization of nanoparticles for nanomedicine. Chem Soc Rev. 2012; 41(7): 2539-44. PubMed Abstract | Publisher Full Text | Free Full Text

36. Seil JT, Webster TJ: Antimicrobial applications of nanotechnology: methods and literature. Int J Nanomedicine. 2012; 7: 2767-81. PubMed Abstract | Publisher Full Text | Free Full Text

37. Bresee J, Bond CM, Worthington RJ, et al:: Nanoscale structure-activity relationships, mode of action, and biocompatibility of gold nanoparticle antibiotics. J Am Chem Soc. 2014; 136(14): 5295-300.

PubMed Abstract | Publisher Full Text

38. Higgins MK, Bokma E, Koronakis E, et al:: Structure of the periplasmic component of a bacterial drug efflux pump. Proc Natl Acad Sci U S A. 2004; 101(27): 9994-9.

PubMed Abstract | Publisher Full Text | Free Full Text

39. F Gu H, Ho PL, Tong E, et al:: Presenting Vancomycin on Nanoparticles to Enhance Antimicrobial Activities. Nano Lett. 2003; 3(9): 1261-3. Publisher Full Text | F1000 Recommendation

40. F Bresee J, Maier KE, Boncella AE, et al:: Growth inhibition of Staphylococcus aureus by mixed monolayer gold nanoparticles. Small. 2011; 7(14): 2027-31. PubMed Abstract | Publisher Full Text | F1000 Recommendation

41. Li X, Robinson SM, Gupta A, et al.: Functional gold nanoparticles as potent antimicrobial agents against multi-drug-resistant bacteria. ACS Nano. 2014 8(10): 10682-6.

PubMed Abstract | Publisher Full Text | Free Full Text

42. Sharma VK, Yngard RA, Lin Y: Silver nanoparticles: green synthesis and their antimicrobial activities. Adv Colloid Interface Sci. 2009; 145(1-2): 83-96. PubMed Abstract | Publisher Full Text

43. Hussain SM, Hess KL, Gearhart JM, et al:: In vitro toxicity of nanoparticles in
BRL 3A rat liver cells. Toxicol In Vitro. 2005; 19(7): 975-83.

PubMed Abstract | Publisher Full Text

44. Fabrega J, Renshaw JC, Lead JR: Interactions of silver nanoparticles with Pseudomonas putida biofilms. Environ Sci Technol. 2009; 43(23): 9004-9. PubMed Abstract | Publisher Full Text

45. F Mahmoudi M, Serpooshan V: Silver-coated engineered magnetic nanoparticles are promising for the success in the fight against antibacterial resistance threat. ACS Nano. 2012; 6(3): 2656-64.

PubMed Abstract | Publisher Full Text | F1000 Recommendation

46. Sherlock SP, Tabakman SM, Xie L, et al.: Photothermally enhanced drug delivery by ultrasmall multifunctional $\mathrm{FeCo} /$ graphitic shell nanocrystals. ACS Nano. 2011; 5(2): 1505-12.

PubMed Abstract | Publisher Full Text | Free Full Text

47. Zharov VP, Mercer KE, Galitovskaya EN, et al:: Photothermal nanotherapeutics and nanodiagnostics for selective killing of bacteria targeted with gold nanoparticles. Biophys J. 2006; 90(2): 619-27.

PubMed Abstract | Publisher Full Text | Free Full Text

48. Kim JW, Shashkov EV, Galanzha El, et al:: Photothermal antimicrobial nanotherapy and nanodiagnostics with self-assembling carbon nanotube clusters. Lasers Surg Med. 2007; 39(7): 622-34. PubMed Abstract | Publisher Full Text

49. F Wu MC, Deokar AR, Liao JH, et al:: Graphene-based photothermal agent for rapid and effective killing of bacteria. ACS Nano. 2013; 7(2): 1281-90. PubMed Abstract | Publisher Full Text | F1000 Recommendation

50. Levy SB, Marshall B: Antibacterial resistance worldwide: causes, challenges and responses. Nat Med. 2004; 10(12 Suppl): S122-9. PubMed Abstract | Publisher Full Text

51. F Kohanski MA, DePristo MA, Collins JJ: Sublethal antibiotic treatment leads to multidrug resistance via radical-induced mutagenesis. Mol Cell. 2010; 37(3): $311-20$

PubMed Abstract | Publisher Full Text | Free Full Text | F1000 Recommendation

52. Kresge CT, Leonowicz ME, Roth WJ, et al:: Ordered mesoporous molecular sieves synthesized by a liquid-crystal template mechanism. Nature. 1992; 359: 710-2. Publisher Full Text

53. F Hetrick EM, Shin JH, Paul HS, et al: Anti-biofilm efficacy of nitric oxidereleasing silica nanoparticles. Biomaterials. 2009; 30(14): 2782-9. PubMed Abstract | Publisher Full Text | Free Full Text | F1000 Recommendation

54. Tian Y, Qi J, Zhang W, et al.: Facile, one-pot synthesis, and antibacterial activity of mesoporous silica nanoparticles decorated with well-dispersed silver nanoparticles. ACS Appl Mater Interfaces. 2014; 6(15): 12038-45. PubMed Abstract | Publisher Full Text

55. Ahamed M, Alsalhi MS, Siddiqui MK: Silver nanoparticle applications and human health. Clin Chim Acta. 2010; 411(23-24): 1841-8.

PubMed Abstract | Publisher Full Text

56. Fabrega J, Luoma SN, Tyler CR, et al.: Silver nanoparticles: behaviour and effects in the aquatic environment. Environ Int. 2011; 37(2): 517-31. PubMed Abstract | Publisher Full Text

57. Anastas P, Eghbali N: Green chemistry: principles and practice. Chem Soc Rev. 2010; 39(1): 301-12. PubMed Abstract | Publisher Full Tex

58. F Richter AP, Brown JS, Bharti B, et al:: An environmentally benign antimicrobial nanoparticle based on a silver-infused lignin core. Nat Nanotechnol. 2015; 10(9): 817-23.

PubMed Abstract | Publisher Full Text | F1000 Recommendation

59. $\mathrm{F}$ Meers $\mathrm{P}$, Neville $\mathrm{M}$, Malinin $\mathrm{V}$, et al.: Biofilm penetration, triggered release and in vivo activity of inhaled liposomal amikacin in chronic Pseudomonas aeruginosa lung infections. J Antimicrob Chemother. 2008; 61(4): 859-68. PublMed Abstract | Publisher Full Text | F1000 Recommendation

60. Kim CS, Duncan B, Creran B, et al.: Triggered Nanoparticles as Therapeutics. Nano Today. 2013; 8(4): 439-47.

PubMed Abstract | Publisher Full Text | Free Full Text

61. F Radovic-Moreno AF, Lu TK, Puscasu VA, et al:: Surface charge-switching polymeric nanoparticles for bacterial cell wall-targeted delivery of antibiotics. ACS Nano. 2012; 6(5): 4279-87.

PubMed Abstract | Publisher Full Text | Free Full Text | F1000 Recommendation

62. F Horev B, Klein MI, Hwang G, et al:: pH-activated nanoparticles for controlled opical delivery of farnesol to disrupt oral biofilm virulence. ACS Nano. 2015; 9(3): 2390-404.

PubMed Abstract | Publisher Full Text | Free Full Text | F1000 Recommendation

63. F Pornpattananangkul D, Zhang L, Olson S, et al:: Bacterial toxin-triggered drug release from gold nanoparticle-stabilized liposomes for the treatment of bacterial infection. J Am Chem Soc. 2011; 133(11): 4132-9. PubMed Abstract | Publisher Full Text | Free Full Text | F1000 Recommendation

64. Giri K, Yepes LR, Duncan B, et al:: Targeting bacterial biofilms via surface engineering of gold nanoparticles. RSC Adv. 2015; 5(128): 105551-9. PubMed Abstract | Publisher Full Text | Free Full Text

65. Duncan B, Landis RF, Jerri HA, et al:: Hybrid organic-inorganic colloidal composite 'sponges' via internal crosslinking. Small. 2015; 11(11): 1302-9.

PubMed Abstract | Publisher Full Text 
Duncan B, Li X, Landis RF, et al:: Nanoparticle-Stabilized Capsules for the Treatment of Bacterial Biofilms. ACS Nano. 2015; 9(8): 7775-82. PubMed Abstract | Publisher Full Text

67. Li SD, Huang L: Pharmacokinetics and biodistribution of nanoparticles. Mol Pharm. 2008; 5(4): 496-504.

PubMed Abstract | Publisher Full Text

68. Arvizo RR, Miranda OR, Moyano DF, et al:: Modulating pharmacokinetics, tumo uptake and biodistribution by engineered nanoparticles. PLoS One. $2011 ; 6(9)$ : e24374.

PubMed Abstract | Publisher Full Text | Free Full Text
69. Cheng CJ, Tietjen GT, Saucier-Sawyer JK, et al.: A holistic approach to targeting disease with polymeric nanoparticles. Nat Rev Drug Discov. 2015; 14(4): 239-47. PubMed Abstract | Publisher Full Text | Free Full Text

70. Longmire M, Choyke PL, Kobayashi H: Clearance properties of nano-sized particles and molecules as imaging agents: considerations and caveats. Nanomedicine (Lond). 2008; 3(5): 703-17.

PubMed Abstract | Publisher Full Text | Free Full Text

71. Kim CS, Le ND, Xing $Y$, et al:: The role of surface functionality in nanoparticle exocytosis. Adv Healthc Mater. 2014; 3(8): 1200-2.

PubMed Abstract | Publisher Full Text | Free Full Text 


\section{Open Peer Review}

\section{Current Peer Review Status:}

\section{Editorial Note on the Review Process}

Faculty Reviews are review articles written by the prestigious Members of Faculty Opinions. The articles are commissioned and peer reviewed before publication to ensure that the final, published version is comprehensive and accessible. The reviewers who approved the final version are listed with their names and affiliations.

\section{The reviewers who approved this article are:}

\section{Version 1}

1. Charles Flexner Johns Hopkins University, Baltimore, MD, USA

Competing Interests: No competing interests were disclosed.

\section{Marco Siccardi}

University of Liverpool, Liverpool, UK

Competing Interests: No competing interests were disclosed.

The benefits of publishing with F1000Research:

- Your article is published within days, with no editorial bias

- You can publish traditional articles, null/negative results, case reports, data notes and more

- The peer review process is transparent and collaborative

- Your article is indexed in PubMed after passing peer review

- Dedicated customer support at every stage

For pre-submission enquiries, contact research@f1000.com 